\title{
Effect of Trade Liberalization on Asymmetric Countries for Homogenous and Differentiate Product: Case of Pakistan-China Free Trade Agreement
}

Author(s): Arsalan Ahmed, Qi Jian Hong, Hassan Tahir

Source: Journal of International Logistics and Trade 2021; 19(1):33-48

Published by: Jungseok Research Institute of International Logistics and Trade, Inha University

DOI: https://doi.org/10.24006/jilt. 2021.19.1.033

Journal of International Logistics and Trade is an official journal published by Jungseok Research Institute of International Logistics and Trade, Inha University, Korea. JILT welcomes manuscripts that advance the practice and science of logistics, trade, and other related fields.

Frequency: Quarterly (March, June, September, December)

Stable URL: https://www.ejilt.org

Jungseok Research Institute of International Logistics and Trade is a specialized academic research institute representing Inha University and Inha Foundation in Korea. The institute aims to become a representative institute in Northeast Asia in the research of logistics and trade.

Stable URL: https://jrieng.inha.ac.kr

(C) Copyright. Jungseok Research Institute of International Logistics and Trade.

This is an Open-Access article distributed under the terms of the Creative Commons Attribution NonCommercial License (http://creativecommons.org/licenses/by-nc/4.0/) which permits unrestricted noncommercial use, distribution, and reproduction in any medium, provided the original work is properly cited 


\title{
Effect of Trade Liberalization on Asymmetric Countries for Homogenous and Differentiate Product: Case of Pakistan-China Free Trade Agreement
}

\author{
Arsalan Ahmed ${ }^{1,2,}{ }^{*}$, Qi Jian Hong ${ }^{2}$, Hassan Tahir ${ }^{3}$ \\ ${ }^{1}$ Dawood University of Engineering \& Technology Karachi, Department of Basic Sciences, Mathematics, English And Humanities, M.A Jinnah Road, Karachi- \\ 74800, Pakistan \\ ${ }^{2}$ Shandong University, Department of International Economics and Trade, 27 Shanda Road, Jinan 250100, China \\ ${ }^{3}$ Ocean University of China, Faculty of Science, Department of Mathematics, 238 Songling Road, Qingdao 266100, China
}

\author{
Received December 04, 2020 \\ Revised February 25, 2021 \\ Accepted March 29, 2021
*Corresponding author: Arsalan Ahmed Dawood University of Engineering \&
Technology Karachi, Department of Basic
Sciences, Mathematics, English And
Humanities, M.A Jinnah Road, Karachi-
74800, Pakistan
Tel: +92-3420035223
E-mail: arsalan.ahmed@duet.edu.pk

\begin{abstract}
The study performs an empirical test to assess the impact of the Pakistan-China Free trade agreement (FTA) on Pakistan, China, and the World's exports under homogenous and differentiated products. This study employs the modeling with Poisson specification with Poisson Pseudo-Maximum Likelihood method for the estimations. The results of empirical test show that the effect of FTA on the FTA and Non-FTA countries is greater in the differentiated product as compared to the homogenous product. Therefore, one of the most important policy implications provided by this study is that export enterprises need to concentrate on differentiated products as compare to the homogenous products after the implementation of the Pakistan-China FTA. Moreover, the previous literature concluded that Pakistan-China FTA was more beneficial for China as compared to Pakistan. However, according to this study, if Pakistani enterprises focus more on differentiated products as compared to homogenous products, then it will be equally beneficial for both Chinese and Pakistani enterprises. This study will contribute to the literature by considering the Bertrand competition between asymmetric countries and find out the effect of the FTA on these three countries. It considers China, Pakistan, and the Rest of the World as first, second, and third countries.
\end{abstract}

Keywords Bertrand competition, Trade liberalization, Differentiated products, Homogenous products, Pakistan-China free trade agreement

\section{Introduction}

The study attempts to address two significant shortcomings in previous literature. Firstly, there is a shortcoming in the literature related to the effect of trade liberalization under Bertrand competition. Secondly, the literature did not explore Pakistan-China free trade agreement (FTA) in the direction of product categories. Initially, this paper provides an introduction about the Pakistan-China economic relation. China and Pakistan are very different economies with respect to both size and structure. The economic size of China is much bigger than Pakistan's. In 2016, the Gross Domestic Product (GDP; nominal) of Pakistan was US\$ 0.3 trillion, while the GDP (nominal) of China was US\$ 11 trillion. The area and population size of Pakistan are relatively smaller than those of China. In Pakistan, 209 million people live in a total area of 304 thousand Square miles. While in China, 1,403 million people live in a total area of 3,705 thousand square miles. In the context of the structure, the economic composition of China is also different from Pakistan. China's economy has a share of $10 \%$ Agriculture, $44 \%$ Industry, and $46 \%$ Services, whereas the economy of Pakistan has a share of $25 \%$ Agriculture, $22 \%$ Industry, and 53\% Services.

Economic and trade relations between Pakistan and China can be traced back to ancient times. Both countries had trade relationships through the famed caravans and the Silk route. The trade route starts from Xinjiang (China) connects with Gilgit (Pakistan) through the Karakoram, forming the central part of the ancient Chinese Silk Road. In the recent era, this route is reexplored by the Chinese government under the project of One Belt One Road (OBOR). While Pakistan becomes an integral part of it through the China Pakistan Economic Corridor (CPEC). This project has made the economic relationship between Pakistan and China more significant than any other country. The value of CPEC is more than 50 billion US\$, which is the highest investment by China in any other country up till now. This significance of the bilateral economic relationship between Pakistan and China was mainly initiated with the Pakistan-China FTA; thus, Pakistan-China FTA is the initial and the core of 
all the economic agreements between Pakistan and China. Historically, the trade interaction between the two nations was characterized by "Coal for Cotton." On 6th January 1963, China and Pakistan "gave the status of "Most Favored Nation" to each other. This event improves the trade relationship between Pakistan and China. In the 1980s, the trade between Pakistan and China increased up to US\$350 million; moreover, the magnitude of bilateral trade between China and Pakistan reaches up to US\$ 700 million in the mid-1990s (Figure 1). China and Pakistan entered into a new level of trade relations while entering the new century. The beginning of the $21^{\text {st }}$ century brought more opportunities for trade and economic relationships for China and Pakistan.

In the last 15 years, the international trade of China has experienced exponential growth. China's export value in 2016 is US\$ 2 trillion (2016), with a trade surplus of US\$ 500 billion. The major export destinations (\% in total Exports) of China are the USA (18\%), Japan (6\%), South Korea (4\%), Germany (3\%), and Vietnam (3\%). China's major import partners ( $\%$ in total imports of China) are South Korea (10\%), Japan (9\%), Taiwan (9\%), USA (9\%), Australia (4\%). Since 2003, Pakistan's exports have grown from US\$ 11 billion (2003) to US\$ 20 billion (2016), while the imports have increased more exponentially. Pakistan's import value has increased from US $\$ 13$ billion (2003) to US $\$ 47$ billion (2016). Pakistan's major exporting partners (\% in total exports) are China (29\%), UAE (13\%), Indonesia (4\%), USA (4\%), and Japan (4\%). In contrast, the leading importing partners (\% in total imports of Pakistan) are the USA (17\%), China (8\%), UK (8\%), Afghanistan (7\%), and Germany $(6 \%)$.

In 2003, the bilateral trade value between China and Pakistan was around US\$ 2.4 billion. Since 2003, the bilateral trade between China and Pakistan has increased by $690 \%$ in 2017. This magnitude of bilateral trade between China and Pakistan was US\$ 19 billion in 2017. In this bilateral trade, China is a much higher contributor than Pakistan. China's export value to Pakistan is US S 17 billion, while Pakistan's export value to China is just US\$2 billion (Figure 2).

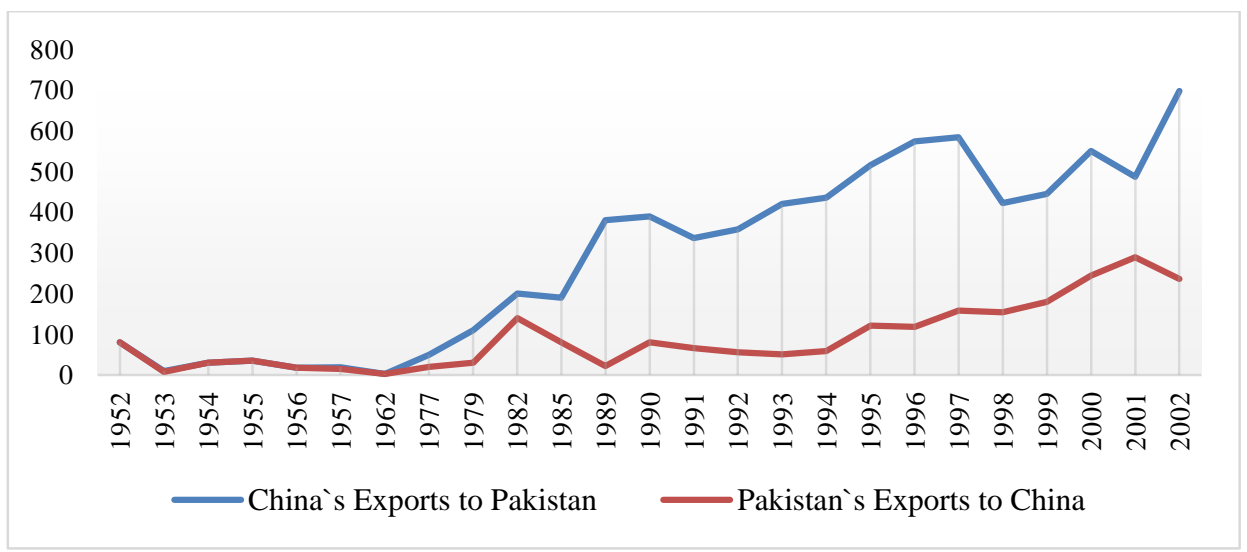

Figure 1. China Pakistan Bilateral Trade US\$ millions (1952-2002). Data from Aziz (1964) and Barnds (1975).

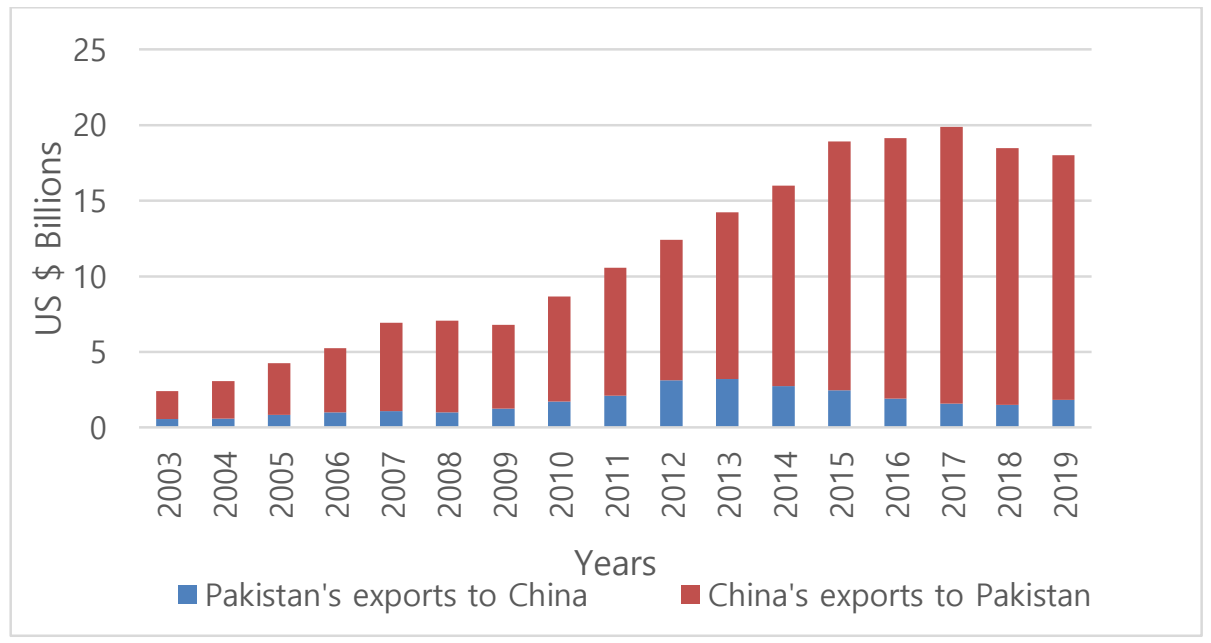

Figure 2. Bilateral trade between China and Pakistan (2003-2019). 
Table 1. Percentage of Bilateral Trade between Pakistan and China

\begin{tabular}{lcc}
\hline Year & Pakistan's share in China's total imports $(\%)$ & China's share in Pakistan's total imports $(\%)$ \\
2003 & 0.14 & 14.18 \\
2004 & 0.11 & 13.76 \\
2005 & 0.13 & 13.67 \\
2006 & 0.13 & 14.21 \\
2007 & 0.12 & 17.89 \\
2008 & 0.09 & 14.29 \\
2009 & 0.13 & 17.48 \\
2010 & 0.12 & 18.49 \\
2011 & 0.12 & 19.37 \\
2012 & 0.17 & 21.18 \\
2013 & 0.16 & 25.17 \\
2014 & 0.14 & 27.85 \\
2015 & 0.15 & 37.37 \\
2016 & 0.12 & 36.66 \\
2018 & 0.08 & 31.83 \\
2019 & 0.09 & 28.09 \\
\hline
\end{tabular}

The proportion of China's commodities in Pakistan's imports has been significantly increasing over the last 15 years. In 2003 the percentage of Chinese commodities in Pakistan's imports was 14\%. Now Chinese products account for $36 \%$ of total imports by Pakistan. China becomes the top importing market of Pakistan. However, Pakistan's contribution to China's imports from the World did not substantially increase in this period. Pakistan's proportion in China`s total imports increase from $0.13 \%$ (2003) to $0.17 \%$ (2012). In 2019, the proportion of Pakistan's commodities in China's imports was dropped to $0.10 \%$ (Table 1 ).

\section{Literature review}

The paper reviews two directions of previous literature. One is related to the effect of trade liberalization under imperfect competition for asymmetric countries. While the other is related to Pakistan-China FTA. In this section, the paper will first discuss the studies related to Pakistan-China FTA. Then it will demonstrate the literature review of trade liberalization under imperfect competition for asymmetric and symmetric countries.

Firstly, according to Javaid and Jahangir (2005), "Pakistan-China strategic relationship is an epitome of enduring friendship, regardless of different belief systems and cultures." On 24th November 2006, the Government of the Islamic Republic of Pakistan and the People's Republic of China signed the FTA. The China-Pakistan FTA covers not only trade but also investment. China's tariff concessions are on finished goods while Pakistan committed tariff reduction on raw material and intermediary goods. According to Kataria and Naveed (2014), Pakistan is the first country located in South Asia that holds a FTA with China, which shows the significance of this FTA. The literature about the Pakistan-China FTA is mainly divided into two major parts: discussion about the opportunities created by the Pakistan-China FTA and the emerging concerns related to Pakistan-China FTA. Some studies show that the Pakistan-China FTA is considered as the origin of new opportunities for strengthening this bilateral cooperation economically (Kamal and Malik 2017; Kayani et al. 2013; Shabir and Kazmi 2007; Zada and Khan 2017). One can be argued that the differences in economic sizes between China and Pakistan could create resistance to achieving the Pakistan-China FTA's goals. However, in a study, Shabir and Kazmi (2007) suggest that Pakistan-China FTA provides a massive potential for Pakistan's economy. Due to the Pakistan-China FTA, Pakistani exporters can have more access to the Chinese market. However, Pakistani exporters need to be more competitive and diversified in utilizing the Pakistan-China FTA. Pakistan-China FTA is not only beneficial for Pakistan, but it is also providing benefits to China too. China evolves as the major trading partner for Pakistan after the implementation of the Pakistan-China FTA. According to Kabraji (2012), this growth was stimulated after the visit of Hu Jintao to Pakistan in 2006, in which both the countries signed a bilateral FTA. The study argued that although the Pakistan-China FTA is more beneficial to China than Pakistan, the main reason for Pakistan's lack is the limited range of commodities exported by Pakistan. 
Moreover, recent literature suggests that Pakistan-China FTA could be a great prospect for Pakistan to boost its exports in the Chinese market. Kayani et al. (2013) find out that Pakistan-China FTA strengthens the economic relations of China-Pakistan. In another study, Kamal and Malik (2017) suggest that Pakistan-China FTA is an excellent opportunity to exploit the vast Chinese market. However, one of the studies also finds the opposite results too. Zada and Khan (2017) show that the effect of the Pakistan-China FTA on Pakistan's economy is modest. This modest effect of the Pakistan-China FTA rains some concerns too. Some of the significant concerns mention in the literature are about the goods convergence, utilization, productivity, and trade deficit (Ahmad 2017; Chaudhry et al. 2017; Musleh-ud et al. 2009; Pakistan Business Council 2012; Qi and Muhammad 2015). Musleh-ud et al. (2009) discuss the issue of the utilization of Pakistan-China FTA. The study mentions that, compared to China, there is a minimal range of products in which Pakistan can specialize its exports to China. They argue that the shortterm effect of FTA between Pakistan and China is tilted towards China. Ahmad (2017) also mentions the same problem of utilization of Pakistan-China FTA for Pakistani exporter. The study finds out that that Pakistani traders only utilize 3.3 percent of tariff concessions given by China under the FTA.

Furthermore, as a whole, the FTA has enhanced bilateral trade, but it has primarily benefitted the Chinese exporters. Qi and Muhammad (2015) argued that even though there is a significant increase in Pakistan-China economic relations, PakistanChina FTA results are not very promising. The study found out that "from a Pakistan perception, FTA covering only goods trade will not be valuable to Pakistan. Pakistan Business Council (2012) explores this concern by analyzing the Pakistan-China FTA. The study found that, although Pakistan-China FTA increased overall bilateral trade volume by 5.9 billion US\$ (since 2006) in this bilateral trade, the share of Pakistan imports China accounts for $70 \%$. Therefore, it creates a significant trade deficit for Pakistan. The issue of Pakistan's trade deficit is concerning given the loss of revenue that Pakistan faces on the exemption of duties (over 230 million US\$ in 2012). The study also highlighted that apart from this trade deficit, China is the main exporter of essential raw material (paper, textiles, iron, and steel industries) and industrial machinery for the Pakistan industry.

Secondly, in trade liberalization, the reduction of the government's trade tariff revenue is compensated by the increment in the consumer surplus of the country's representative consumers. However, the profit of the domestic and international firms changes the welfare level more significantly. In the literature, the studies mainly explore trade liberalization on domestic and international firms under imperfect market conditions. The studies about the effect of trade liberalization in the presence of an Imperfect Market are separated according to their assumptions of product categories, market size, and type of imperfect market. The central assumptions include homogenous vs. differentiated products, symmetric vs. asymmetric countries, and Bertrand vs. Cournot competition. Initially, Brander (1981) and Brander and Krugman (1983) established trade theories for imperfect competition. Their studies highlighted the welfare effects of trade liberalization in the Cournot model of homogeneous products. According to the Brand and Krugman model, if the initial transportation cost is too high, free trade will reduce welfare. After Brander and Krugman, many studies in the literature explore the effect of trade under Cournot competition. In Cordella (1993), he explores Cournot oligopoly with many firms in each country, assuming linear demand functions and zero marginal costs. The study found that "only if the number of foreign companies is much greater than the number of domestic companies can a country benefit from unilateral free trade." In another study, Collie (1996) suppose homogeneous products with the linear demand function. This study shows that "having same marginal cost is harmful to both the firms, while only if a foreign company has a significant cost advantage then a country will benefit from unilateral free trade". Other studies have also considered the different sizes of countries under Cournot competition (Chang and Xiao 2015; Kiyotaki and Miyakawa 2013; Saggi 2006; Yamamoto 2014). Saggi (2006) determines the way FTAs are formed and the number of (FTA) affect the possibility of obtaining global free trade. It develops the equilibrium theory of the formation of free trade areas and derives the stable Nash equilibrium of the two trade liberalization games among three (symmetric or asymmetric) countries. While comparing the results for symmetric and asymmetric country size under Cournot competition in homogenous goods, Kiyotaki and Miyakawa (2013) examine the formation of bilateral FTAs in the context of a dynamic non-cooperative bargaining game with a random proposer. They find out that the FTA in the case of both symmetric and asymmetric countries FTA always benefits unequally; in symmetric countries, there is an advantage of the first mover, and in the asymmetric country there is an advantage of bargaining power for big countries, so WTO is better than FTA. In a similar study Yamamoto (2014) explores two outstanding features of FTAs, the first feature is that the increase in FTAs among various market-sized countries. Whereas, the second feature is that the existence of a small country's implicit side payments. The study examines FTA negotiations between two asymmetric countries when informational asymmetry exists about the small country's market size. This study finds out that "the large country sometimes chooses the smaller market-sized country as its FTA partner for acquiring a larger amount of side payments". Besides, a small country can lead the large one to accept the FTA offer by suggesting side payments in advance. Likewise, Chang and Xiao (2015) discuss the member states of different market sizes concerning the difference in welfare 
between free trade areas (FTA) and customs unions (CU). In the stylized three-country trade model under oligopoly, the study illustrates that FTA members set external tariffs for encouraging the export companies to comply with the rules of origin within the trading group. Due to the positive attitude, it helps eliminates the trade bias and institutional changes that lead to the formation of effective FTAs. In literature, some studies analyze the effect of trade liberalization under Cournot competition for differentiated products. While considering the case of differentiated products, Krzysztof (2016) study the magnitude of welfare for the processes of trade liberalization between asymmetric states with respect to the in sizes and effectiveness of their market and the nature of international exchange. The study found that "the trade liberalization improves the social welfare if trade barriers between industries or vertical industries are smaller than the difference in economic efficiency. In another study based on differentiated products, Kawabata et al. (2010) studied the change in tariff and welfare of vertical trade due to trade liberalization. The study supposed a model based on the three markets model and suggests that the FTA inevitably forces to decline the tariff of member countries, while the tariff of nonmember countries could experience a growth, also the FTA increased the country's welfare.

In contrast to the Cournot competition, the previous studies also discussed the effect of Trade liberalization under Bertrand competition. Bernhofen (2001) dated product differences into the intra-industry trade oligopoly model of Cunei and Bertrand between two identical countries. Although the study finds out the impact of trade on profits and consumer surplus under the Cournot oligopoly, the study shows its limitation with respect to the impact of trade on the welfare under the Bertrand oligopoly. Gurtzgen (2002) attempted to understand the consequences of trade liberalization for union wages in a context of a differentiated Bertrand duopoly. The study suggested that if demand for the domestic product strongly depends on foreign prices of complementary goods then Product market integration diverges the domestic wages. In another study, Friberg and Ganslandt (2005) examine the impact of international trade on the total welfare in an international oligopoly under differentiated goods. The study illustrates that under Bertrand competition there could be a decline in welfare by the free trade as compared to autarky in the case of close substitute products by the firms. While the autarky equilibrium can be adequately competitive. While considering the Bertrand competition most of the studies hold the assumption of symmetric countries size (Ashournia et al. 2013; Collie and Le 2014; Kawabata and Takarada 2015; Yang and Kyung 2014) however few of them take the assumption of asymmetric country size. For the case of symmetric country size, Kawabata and Takarada (2015) consider a model of three markets for Bertrand and Cournot competition in differentiated oligopolies and find out the impact of FTAs on the welfare of the countries. Moreover, this analysis is conducted for both the member and non-member countries. They show that due to the product differentiation the welfare of all member states and non-member states in the Bertrand-Cournot competition experience growth by the FTAs. However, in the case of homogenous products, there is less incentive for a nonmember country to support multilateral trade liberalization with Bertrand competition with the presence of FTA. While this result is opposite in under the Cournot competition. Similarly, Collie and Le (2014) employed the Shubik-Levitan demand functions and analyze the impact of product differentiation on the volume of trade under duopoly, their study concludes that if the cost of trade is positive then Cournot completion experienced some better positive results as compared to the Bertrand competition under trade liberalization. Also, with the same assumption of symmetric country size Ashournia et al. (2013) explore "how a reduction in trade costs influences the possibility for firms to engage in international cartels, and hence how trade liberalization affects the degree of competition". The study finds out that, under all kinds of competition there is a possibility of anti-competitiveness after the trade liberalization, which is opposite to the general perception of trade theory. Furthermore, Yang and Kyung (2014) study Bertrand's competition for substitutes and complements products beneath the multilateral free trade. The study illustrates that the consumer surpluses, the producer surpluses, and the welfare of both domestic and the foreign market, are greater in the case of substitute products as compared to the complement's products. Also, Clarke and Collie (2003) introduce differentiated Bertrand duopoly into the Brander-Krugman model to reconsider trade gains for symmetric. While assuming a representative consumer with a quadratic utility function, they demonstrate that welfare in trade is larger than welfare in autarky for any transport cost, i.e., any trade is better than autarky. This is because the consumer enjoys a wider variety of differentiated goods at a lower price by freer trade, which overweighs the negative effects. However, in contradictions to the results of Clarke and Collie (2003), Fujiwara (2009) develops a two-country Hoteling model of spatial duopoly to consider the welfare effects of multilateral transport cost reductions. While considering the elasticity of demand, they show that welfare in trade becomes less than welfare in autarky for any level of trade cost.

In summary, the study finds a major gap in the previous for the Bertrand competition. In the literature, we could not find any substantial study that analyzed the effect of trade liberalization under bartend competition for three asymmetric countries, it leads to the marginal contribution of this study. This study will analyze the effect of trade liberalization under bartered competition for three asymmetric countries. 


\section{Two shortcomings of previous studies}

In the previous literature (Ashournia et al. 2013; Bernhofen 2001; Brander 1981; Brander and Krugman 1983; Chang and Xiao 2015; Clarke and Collie 2003; Collie 1996; Collie and Le 2014; Cordella 1993; Friberg and Ganslandt 2005; Fujiwara 2009; Kawabata and Takarada 2015; Kawabata et al. 2010; Kiyotaki and Miyakawa 2013; Krzysztof 2016; Saggi 2006; Yamamoto 2014; Yang and Kyung 2014), it can be observed that when exploring the effect of trade liberalization on welfare, there is a gap for the case of Bertrand competition under asymmetric country. There could be very few studies that follow these conditions; however, there is no single study that analyses the effect of trade liberalization on all three countries under Bertrand competition for the asymmetric countries. Whereas, the real-world scenario is closer to the Bertrand competition between asymmetric countries. Therefore, this study attempts to fill this gap. This study will contribute to the literature by considering the Bertrand competition between asymmetric countries and empirically finding out the FTA's effects on these three countries.

Moreover, the previous literature related to the Pakistan-China FTA clearly shows an ambiguous understanding of the Pakistan-China FTA. There is a lack of concrete solutions for the improvement in the Pakistan-China FTA. Meanwhile, the previous studies did not explore the Pakistan-China FTA's direction under the product categories of homogenous and differentiated products. Therefore, the study will attempt to fill this gap by analyzing the export value and dual margin of trade for homogenous and differentiated commodities under the Pakistan-China FTA. Hence, it attempts to address both of these two gaps simultaneously.

\section{Empirical analysis}

\subsection{Dataset}

The study uses the panel data set from 2003 to 2017. The data is collected for the cases of Pakistan, China, and the Rest of the world. The dataset is based on the 8-Digits Harmonized Commodity Description and Coding System. The results' estimation is more robust and consistent with the real-world scenarios using the HS 8-Digits. The HS comprises approximately 5,300 articles/product descriptions that appear as headings and subheadings, arranged in 99 chapters, grouped in 21 sections. The data of Gross Domestic Products (GDP) is taken from the World Bank ${ }^{1}$. The data of the distance is obtained from the CEPII (Centre d'Etudes Prospectives et d'Informations Internationales) ${ }^{2}$. Also, the export data is collected from a single source of the International Trade Center ${ }^{3}$. Further, the data related to Pakistan-China FTA is obtained from the "Ministry of commerce (People's Republic of China)." ${ }^{4}$ Besides, the study employed product classification by Rach $(1999)^{5}$ for homogenous and differentiated products. This classification is based on the four-digit Standard International Trade Classification (SITC) Revision 2. Therefore, the study converts these SITC codes to HS codes with the help of available correspondence tables ${ }^{6}$. The classification by the Rach is available in two versions. One is conservative, and the other is liberal. The study uses conservative as a baseline test, while the liberal criteria use in robust tests.

\subsection{Dependent variables}

\subsubsection{Export's value $\left(T_{i j, k, t}\right)$}

The variable $T_{i j k t}$ is defined as the value of exports in US\$ by the country $i$ to the country $j$ for the HS commodity digit code $k$ in the year $t$. The variable is estimated directly from the available data.

\subsubsection{Extensive margin of trade $\left(E M_{i j, k, t}\right)$}

The variable $E M_{i j k t}$ is defined as the number of products exported by the country $i$ to the country $j$ for the HS commodity digit code $k$ in the year $t$. The measuring formula for this variable is as follow:

\footnotetext{
${ }^{1}$ https://data.worldbank.org/

${ }^{2}$ http://www.cepii.fr/CEPII/en/bdd_modele/bdd_modele.asp

${ }^{3} \mathrm{http}: / /$ www.intracen.org/itc/market-info-tools/trade-statistics/

${ }^{4} \mathrm{http}: / / \mathrm{fta} . \mathrm{mofcom} . \mathrm{gov} . \mathrm{cn} /$ Pakistan/Pakistan_special.shtml

${ }^{5}$ http://www.macalester.edu/research/economics/page/haveman/Trade.Resources/TradeData.html

${ }^{6} \mathrm{http}: / /$ www.macalester.edu/research/economics/page/haveman/Trade.Resources/tradeconcordances.html
} 


$$
E M_{i j, k, t}=\sum_{k} N_{i j t}
$$

where " $N$ " is the number of products exported by the country, $i$ is the exporting country, $j$ is the importing country, $k$ is the HS commodity digit code, and $t$ is the year.

\subsubsection{Intensive margin of trade $\left(I M_{i j, k, t}\right)$ :}

The variable $I M_{i j k t}$ is defined as the average value of an exported commodity by the country $i$ to the country $j$ for the HS commodity digit code $k$ in the year $t$. The measuring formula for this variable is as follow:

$$
I M_{i j k t}=\frac{\sum_{k} T_{i j t}}{\sum_{k} N_{i j t}}
$$

where, "T $T_{i j k t}$ " is the value of exports in US\$ by country $i$ to country $j$ for the HS commodity digit code $k$ in the year $t$ and " $N_{i j k t}$ " is the number of products exported by country $i$ to country $j$ for the HS commodity digit code $k$ in the year $t$.

\subsection{Independent variable}

The dummy Pakistan-China FTA is used to capture the effect of the Pakistan-China FTA. The dummy takes the value as "1" for the specific case of " $k i t$ " and remains " 0 " for other cases. Here, " $k$ " is for the commodities that are included in the Pakistan-China FTA, " $i$ " is the exporting country/region, and " $t$ " is the years in which the Pakistan-China FTA implement. The sign of this dummy can be positive or negative.

\subsection{Controlling variables}

\subsubsection{Gross domestic products $\left(G D P_{i j t}\right)$}

The variable of Gross Domestic Products $\left(G D P_{i j t}\right)$ is defined as the size of the importing and exporting market. This variable is estimated as the multiplication of the GDP of the exporting country and the importing country. The formula for this variable is as follow:

$$
\left(G D P_{i j t}\right)=\left(G D P_{i t} \times G D P_{j t}\right)
$$

where GDP is the GDP of the country, $i$ is the exporting country, $j$ is the importing country, and $t$ is the year.

\subsubsection{Distance $\left(\right.$ Dist $\left._{i j t}\right)$}

The variable of distance $\left(\right.$ Dist $\left._{i j t}\right)$ is defined as the geographical distance between the countries. The distance is calculated following the great circle formula, which uses latitudes and longitudes of the most important cities/agglomerations (in terms of population). Also, it incorporates internal distances based on areas. The detail of this calculation is mentioned in the report published by CEPII ${ }^{7}$.

\subsubsection{Trade openness $\left(\mathrm{TO}_{i, t}\right)$}

The variable of trade openness is defined as the imports (percentage of GDP) by the exporting country divided by the import (percentage of GDP) by the rest of the World. The formula for the variable is as follow:

$$
T O_{i, t}=\frac{\operatorname{Im}(\% G D P)_{i, t}}{\operatorname{Im}(\% G D P)_{\text {row }, t}}
$$

where $\operatorname{Im}(\% G D P)$ is the import as a percentage of GDP of the country, $i$ is the exporting country, row is the region except

${ }^{7}$ http://www.cepii.fr/PDF_PUB/wp/2011/wp2011-25.pdf 
the exporting country, and $t$ is the year.

\subsubsection{Inflation $\left(I N F_{i j t}\right)$}

The variable of inflation $\left(I N F_{i j t}\right)$ is defined as the consumer price index. It is measure by the annual percentage change in the cost to the average consumer of acquiring a basket of goods and services. This variable is estimated as the multiplication of inflation of the exporting country and the importing country. The formula for this variable is as follow:

$$
\left(I N F_{i j t}\right)=\left(I N F_{i t} \times I N F_{j t}\right)
$$

where $i$ is the exporting country, $j$ is the importing country, and $t$ is the year.

\subsubsection{Exchange rate $\left(E X R_{i j t}\right)$}

The variable of exchange rate $\left(E X R_{i j t}\right)$ is defined as the value of a nation's currency in terms of the trading partner's currency. Where $i$ is the exporting country, $j$ is the importing country, and $t$ is the year.

\subsection{Baseline gravity model}

In the literature, the gravity equation had played a dominant role in finding out the effect of the FTA on bilateral trades. Generally, in the gravity equation, the dependent variable is the exports of country $i$ to country $j$. whereas the independent variable includes the factors that either support or resist these exports. Also, the dummies are employed to quantify the effect of trade agreements on bilateral trade among the countries. Thereby, the general specification of the gravity model can be shown by the following equation ${ }^{8}$ :

$$
\ln \left(T_{i j t}\right)=B_{0}+B_{1} \times \ln \left(G_{i t}\right)+B_{2} \times \ln \left(G_{j t}\right)+B_{3} \times \ln \left(D_{i j}\right)+B_{4} \times\left(F T A_{i j t}\right)+U_{i j t}
$$

where, $T_{i j k t}$ is the exports from the country $i$ to country $j$ at time $t$ of product category $k, G_{i t}$ is the size of the economy of country $i$ at time $t, G_{j t}$ is the size of the economy of country $j$ at time $t, D_{i j}$ is the bilateral distance between country $i$ and country $j$, and $F T A_{i j t}$ is the FTA dummy between country $i$ and country $j$ at time $t$.

\subsection{Modeling issues}

\subsubsection{Endogeneity in sample selection}

The speciation of the gravity model is based on the log-liner model. Therefore, one of the critical issues of the gravity model is incompatibility with the zero trade flow data. The Log-linear regression model only accounts for the positive trade flow data. While using only positive trade flow makes the estimation biased. This selection biasness occurs when the study systematically excludes a specific part of data based on some particular conditions (Heckman 1979; Helpman et al. 2008; Wooldridge 2006) In literature, the studies argue that the presence of zero trade flows in trade data is due to the effect of trade barriers; hence it is not random.

While others mention that using OLS, the estimator parameters must be biased if the regressed have the presence of sample selection biasness. The study uses the methodology of Poisson pseudo-maximum likelihood (PPML) estimation to resolve this endogeneity in the sample selection.

\subsubsection{Heteroskedastic residuals}

Another major problem in the log-liner model is heteroskedastic residuals. In the OLS regression, it is assumed that all the residual that is drawn from the population holds a constant value of variance among them. If the variance of the residuals does

${ }^{8}$ By using the mathematical rule of $\ln (a)+\ln (b)=\ln (a \times b)$, this study utilizes the multiplicative form of these two GDPs. It is similar to the Pham (2014), Shaista (2013) and Thai (2006). 
not remain constant then the residuals are considered as heteroscedasticity. Furthermore, in the presence of heteroskedastic residuals, the estimates are not consistent (Silva and Tenreyro 2006). The issue of heteroscedasticity residuals is illustrated as follow:

Consider a stochastic form of the traditional gravity model of trade with exports from country $i$ to $j$ denoted by $T_{i j}$, is directly proportional to the product of the two countries Size $G_{i}, G_{j}$ and inversely proportional to the distance $D i j$ between them.

$$
T_{i j}=\left(\beta_{0}\right)\left(\left(G_{i} G_{j}\right)^{\beta_{1}}\right)\left(D_{i j}\right)^{\beta_{2}}(u i j)
$$

In the OLS model, it is assumed that give that the values of residuals term are random, uncorrelated with the independent variable, and have the expected value of one.

$$
\begin{aligned}
& E\left[u i j \mid\left(\beta_{0}\right)\left(\left(G_{i} G_{j}\right)^{\beta_{1}}\right)\left(D_{i j}\right)^{\beta_{2}}\right]=1 \\
& E\left[T i j \mid\left(G_{i} G_{j}\right)^{\beta_{1}},\left(D_{i j}\right)^{\beta_{2}}\right]=\left(\beta_{0}\right)\left(\left(G_{i} G_{j}\right)^{\beta_{1}}\right)\left(D_{i j}\right)^{\beta_{2}}
\end{aligned}
$$

For the estimating of parameters, traditionally the gravity model is specified in the form of the log-liner model, that is:

$$
\ln \left(T_{i j}\right)=B_{0}+B_{1} \times \ln \left(G_{i} \times G_{j}\right)+B_{2} \times \ln \left(D_{i j}\right)+\ln \left(U_{i j}\right)
$$

It is important to highlight that the regression in the above equation holds its validity only if the log of residuals $\ln \left(U_{i j}\right)$ are also independent of the regressand. However, according to Jensen's inequality, the expected value of the log of a random variable (in this case is residuals) is not equal to the log of its expected value. Also, it depends on the higher-order moments of its distribution. That is:

$$
E[\ln (u i j)] \neq \ln [E(u i j)]
$$

While considering Jensen's inequality one can conclude that if the variance of the residual term uij depends on the dependent variables, then the $E[\ln (u i j)]$ will also depend on the independent variables; hence the OLS estimator will not be consistent.

\subsubsection{Poisson specification and PPML}

This study employs the modeling with Poisson specification to solve the issue of sample selection endogeneity and heteroscedastic residuals. In Poisson specification, one can estimate the gravity equation in the multiplicative form and allow for heteroscedasticity (Silva and Tenreyro 2006).

$$
T_{i j}=e^{\left\{B_{0}+B_{1} \times \ln \left(G_{i} \times G_{j}\right)+B_{2} 0 \times \ln \left(D_{i j}\right)+\ln \left(U_{i j}\right)\right\}}
$$

This study uses the method of PPML with Poisson specification for the empirical estimations for two reasons. The first reason is that PPML assumed that conditional variance is proportional to the conditional mean. That is:

$$
E\left(T_{i j} \mid Z\right) \propto V\left(T_{i j} \mid Z\right)
$$

Given this assumption, the consistency of the Poisson model holds with the mis specified variance function. Silva and Tenreyro (2006) shows that the PPML estimator is likely to be more efficient than other estimators even if $E(T i j \mid Z) \propto$ $V(T i j \mid Z)$ does not hold when heteroscedasticity increases with the conditional mean. The only requirement for the consistency of this estimator is the correct form of the conditional mean. Therefore, it will not only be applicable for the non-Poisson data, but the dependent variable can also be non-integer, still, the estimator will be consistent.

The second reason is that the dependent variable does not have to be count data in case of for PPML estimation. Moreover, whenever the conditional mean assumption holds the fixed effect Poisson estimator are correctly utilized. It indicates that 
dependent variables could be defined as nonnegative continuous variables. Furthermore, in order to estimate random effect Poisson model, the model required additional assumptions for efficiency as compared to the fixed effect Poisson model. In this study, the Hausman specification test rejects the random effect model in favor of the fixed-effect model. Hence, the fixed-effect Poisson model is used in this analysis. Hence the final equation for the empirical estimation will be:

$$
\left.T_{i j k t}=e^{\left\{\begin{array}{c}
B_{0}+B_{1} \times \ln \left(G D P_{i t} \times G D P_{j t}\right)+B_{2} \times \ln \left(\text { Distance }_{i j}\right)+B_{3} \times \ln \left(T O_{i t}\right)+ \\
B_{4} \times\left(\text { PCFTA }_{i j k t}\right)+B_{5} \times \ln \left(I N F_{i, j, t}\right)+B_{6} \times \ln \left(E X R_{i, j, t}\right)+\text { indiviual fixed effect }+ \text { time fixed effect }
\end{array}+U_{i j k t}\right.}\right\}
$$

$T_{i j k t}$ is the exports from the country $i$ to country $j$ at time $t$ of product categoryk, GDP $P_{i t}$ and $G D P_{i t}$ is the size of the economy of country $i$ and country $j$ at time $t$, Distance Dij $_{i j}$ is the bilateral geographical distance between country $i$ and country $j, T O_{i t}$ is the trade openness by country $i$ at time $t$ for commodity $k$.and PCFTA $A_{i j t}$ is the FTA dummy between country $i$ and country $j$ at time $t$ for commodity $k$.

\subsection{Dual margin of trade}

Let consider the " $T_{i j}$ " is the total exports from the country $i$ to country $j$. If " $T_{i j}$ " multiply and divide by the number of exporting commodities $\left(N_{i j}\right)$ then the equation will still hold equality. Thereby, the equation will be as follow:

$$
T_{i j}=\left(N_{i j}\right)\left(\frac{T_{i j}}{N_{i j}}\right)
$$

Here, in the above equation the term $\left(N_{i j}\right)$ can be considered as the extensive $\operatorname{margin}\left(E M_{i j k t}\right)$, while the term $\left(\frac{T_{i j}}{N_{i j}}\right)$ can be defined as the intensive margin. Thereby, the above equation 6 can be rewritten as the following equation.

$$
\begin{aligned}
& T_{i j}=\left(E M_{i j}\right)\left(I M_{i j}\right) \\
& \ln \left(T_{i j k t}\right)=\ln \left(\left(E M_{i j}\right)\left(I M_{i j}\right)\right) \\
& \ln \left(T_{i j}\right)=\ln \left(E M_{i j}\right)+\ln \left(I M_{i j}\right)
\end{aligned}
$$

Now, from equation 1 and equation 6 the study can derive the equations for the extensive margin and intensive margin of trade. Equation 9 and equation 10 represent the equations for the extensive margin and intensive margin of trade as follow:

$$
\begin{aligned}
& \ln \left(E M_{i j k t}\right)=B_{0}+B_{1} \times \ln \left(G D P_{i j t}\right)+B_{2} \times \ln \left(\text { Distance }_{i j}\right)+B_{4} \times\left(D F T A_{i j k t}\right)+B_{5} \times \ln \left(I N F_{i j t}\right)+B_{6} \times \ln \left(E X R_{i j t}\right) \\
& +\left(U_{i j t}\right) \\
& E M_{i j k t}=e^{\left\{\begin{array}{c}
B_{0}+B_{1} \times \ln \left(G D P_{i t} \times G D P_{j t}\right)+B_{2} \times \ln \left(\text { Distance }_{i j}\right)+B_{3} \times \ln \left(T O_{i t}\right)+ \\
B_{4} \times\left(P C F T A_{i j k t}\right)+B_{5} \times \ln \left(I N F_{i, j, t}\right)+B_{6} \times \ln \left(E X R_{i, j, t}\right)+\text { indiviual fixed effect }+ \text { time fixed effect }+U_{i j k t}
\end{array}\right\}} \\
& \ln \left(I M_{i j k t}\right)=B_{0}+B_{1} \times \ln \left(G D P_{i j t}\right)+B_{2} \times \ln \left(\text { Distance }_{i j}\right)+B_{4} \times\left(D F T A_{i j k t}\right)+B_{5} \times \ln \left(I N F_{i j t}\right)+B_{6} \times \ln \left(E X R_{i j t}\right) \\
& +\left(U_{i j t}\right) \\
& I M_{i j k t}=e^{\left\{\begin{array}{c}
B_{0}+B_{1} \times \ln \left(G D P_{i t} \times G D P_{j t}\right)+B_{2} \times \ln \left(\text { Distance }_{i j}\right)+B_{3} \times \ln \left(T O_{i t}\right)+ \\
B_{4} \times\left(\text { PCFT }_{i j k t}\right)+B_{5} \times \ln \left(I N F_{i, j, t}\right)+B_{6} \times \ln \left(E X R_{i, j, t}\right)+\text { indiviual fixed effect }+ \text { time fixed effect }+U_{i j k t}
\end{array}\right\}}
\end{aligned}
$$

\section{Results}

Table 2 demonstrates the result of empirical estimation. The effect of Pakistan-China FTA on the value of Pakistan's exports to the World, China's exports to the world, and world exports to Pakistan are higher for differentiation as compare to the homogenous products. Meanwhile, the results of this study also show that the effect of the Pakistan-China FTA on the value of 
Table 2. Baseline estimation for the Pakistan-China FTA

\begin{tabular}{|c|c|c|c|c|c|}
\hline \multicolumn{2}{|c|}{ Variable } & $\begin{array}{l}\text { PCFTA_Homogenous } \\
\text { products }\end{array}$ & $\begin{array}{l}\text { (No. of Obs.) } \\
\text { Prob > chi } 2\end{array}$ & $\begin{array}{c}\text { PCFTA_Differentiated } \\
\text { products }\end{array}$ & $\begin{array}{l}\text { (No. of Obs.) } \\
\text { Prob > chi } 2\end{array}$ \\
\hline \multirow[t]{3}{*}{$\begin{array}{l}\text { Pakistan exports to } \\
\text { China/row }\end{array}$} & Value & $\begin{array}{l}-1.0123^{* * *} \\
(0.3479)\end{array}$ & $\begin{array}{l}(2727) \\
0.0000\end{array}$ & $\begin{array}{l}1.1014^{* * *} \\
(0.3519)\end{array}$ & $\begin{array}{c}(22050) \\
0.0000\end{array}$ \\
\hline & $\begin{array}{l}\text { Intensive } \\
\text { margin }\end{array}$ & $\begin{array}{l}-0.8408^{* * *} \\
(0.3246)\end{array}$ & $\begin{array}{l}(2727) \\
0.0000\end{array}$ & $\begin{array}{l}0.9886^{* * * *} \\
(0.4487)\end{array}$ & $\begin{array}{c}(22050) \\
0.0000\end{array}$ \\
\hline & $\begin{array}{l}\text { Extensive } \\
\text { margin }\end{array}$ & $\begin{array}{l}-0.2833^{*} \\
(0.1631)\end{array}$ & $\begin{array}{l}(2742) \\
0.0000\end{array}$ & $\begin{array}{l}0.2189^{* * *} \\
(0.0761)\end{array}$ & $\begin{array}{c}(22140) \\
0.0000\end{array}$ \\
\hline \multirow[t]{3}{*}{$\begin{array}{l}\text { China exports to } \\
\text { Pakistan/row }\end{array}$} & Value & $\begin{array}{l}-0.4619^{*} \\
(0.2587)\end{array}$ & $\begin{array}{l}(4380) \\
0.0000\end{array}$ & $\begin{array}{l}0.3068^{* * *} \\
(0.1426)\end{array}$ & $\begin{array}{c}(55170) \\
0.0000\end{array}$ \\
\hline & $\begin{array}{l}\text { Intensive } \\
\text { margin }\end{array}$ & $\begin{array}{l}-0.9328^{* * *} \\
(0.3292)\end{array}$ & $\begin{array}{l}(4380) \\
0.0000\end{array}$ & $\begin{array}{l}0.3650^{* * *} \\
(0.1050)\end{array}$ & $\begin{array}{c}(55170) \\
0.0000\end{array}$ \\
\hline & $\begin{array}{l}\text { Extensive } \\
\text { margin }\end{array}$ & $\begin{array}{l}0.0667 \\
(0.1264)\end{array}$ & $\begin{array}{l}(4380) \\
0.0000\end{array}$ & $\begin{array}{l}0.0389^{*} \\
(0.0231)\end{array}$ & $\begin{array}{c}(55170) \\
0.0000 \\
\end{array}$ \\
\hline \multirow[t]{3}{*}{$\begin{array}{l}\text { World exports to } \\
\text { Pakistan/row }\end{array}$} & Value & $\begin{array}{l}-0.2266^{*} \\
(0.1252)\end{array}$ & $\begin{array}{l}(5598) \\
0.0000\end{array}$ & $\begin{array}{l}0.1526 \\
(0.1468)\end{array}$ & $\begin{array}{c}(55749) \\
0.0000\end{array}$ \\
\hline & $\begin{array}{l}\text { Intensive } \\
\text { margin }\end{array}$ & $\begin{array}{l}-0.2836^{* * *} \\
(0.1034)\end{array}$ & $\begin{array}{l}(5598) \\
0.0000\end{array}$ & $\begin{array}{l}0.2945^{*} \\
(0.1714)\end{array}$ & $\begin{array}{c}(55749) \\
0.0000\end{array}$ \\
\hline & $\begin{array}{l}\text { Extensive } \\
\text { margin }\end{array}$ & $\begin{array}{l}0.0802^{*} \\
(0.0454)\end{array}$ & $\begin{array}{l}(5613) \\
0.0000\end{array}$ & $\begin{array}{l}0.0295^{*} \\
(0.0178)\end{array}$ & $\begin{array}{c}(55912) \\
0.0000\end{array}$ \\
\hline \multirow[t]{3}{*}{$\begin{array}{l}\text { World exports to } \\
\text { China/row }\end{array}$} & Value & $\begin{array}{l}-0.8539^{* * *} \\
(0.3457)\end{array}$ & $\begin{array}{l}(1820) \\
0.0000\end{array}$ & $\begin{array}{l}-1.4536^{* *} \\
(0.6559)\end{array}$ & $\begin{array}{c}(17570) \\
0.0000\end{array}$ \\
\hline & $\begin{array}{l}\text { Intensive } \\
\text { margin }\end{array}$ & $\begin{array}{l}-0.7141^{* * *} \\
(0.2796)\end{array}$ & $\begin{array}{l}(1820) \\
0.0000\end{array}$ & $\begin{array}{l}-1.5249^{* *} \\
(0.6581)\end{array}$ & $\begin{array}{c}(17570) \\
0.0000\end{array}$ \\
\hline & $\begin{array}{c}\text { Extensive } \\
\text { margin }\end{array}$ & $\begin{array}{l}-0.0208 \\
(.0732)\end{array}$ & $\begin{array}{l}(1820) \\
0.0450\end{array}$ & $\begin{array}{l}-0.0519^{*} \\
(0.0300)\end{array}$ & $\begin{array}{c}(17570) \\
0.0000\end{array}$ \\
\hline
\end{tabular}

${ }^{*} p<0.1,{ }^{* *} p<0.05,{ }^{* * * *} p<0.01$.

FTA, free trade agreement.

world export to China is negative for both the differentiated product and homogenous products. Additionally, the impact of the establishment of the Pakistan-China FTA on the intensive margin of Pakistan's exports to China, China's exports to Pakistan, and World exports to Pakistan are found to be higher for differentiated products as compared to the homogenous product. Lastly, the effect of the establishment of the Pakistan-China FTA on the extensive margin of Pakistan's exports to China is found to be higher for differentiated products as compared to the homogenous product. In contrast, this effect is higher in homogenous products than Differentiated products in China's exports to Pakistan and World exports to Pakistan. Besides, the establishment of the Pakistan-China FTA negatively affects the dual margins of the World's exports to China in both homogenous and differentiated products.

\section{Robustness tests}

The study conducts three robustness tests to ensure the credibility of the results. The first robustness test for the baseline results is based on different classifications (liberal) for homogenous and differentiated products (discussed earlier in the section of "DATA"). Also, the second robustness test used the different specifications of independent variables ${ }^{9}$ while using the data sample under conservative criteria (same as baseline estimation's data set). In the third robustness test, the study used the different specifications of independent variables with the data sample under liberal criteria of classifications.

The study compares the baseline results and robustness test results and explores the similarity or differences between them. The results ${ }^{10}$ of these robustness tests are presented in Table 3, Table 4, and Table 5. The results of first robustness test in Table 3 demonstrates that most of the estimated coefficients of independent variables of robustness tests are similar to the estimated coefficient of independent variables under baseline estimation except a few. The coefficient of Pakistan-China FTA dummy of

${ }^{9}$ The detail of this calculation is mentioned report published by CEPII. http://www.cepii.fr/PDF_PUB/wp/2011/wp2011-25.pdf $10^{*}, * *, * *$ means the significance of level at 10,5 , and 1 percent. 
Table 3. Frist Robustness test estimation for the Pakistan-China FTA

\begin{tabular}{|c|c|c|c|c|c|}
\hline \multicolumn{2}{|c|}{ Variable } & \multirow{2}{*}{$\begin{array}{c}\text { PCFTA_Homogenous } \\
\text { products } \\
-0.6712^{*} \\
(0.3711)\end{array}$} & \multirow{2}{*}{$\begin{array}{c}\text { (No. of Obs.) } \\
\text { Prob > chi2 } \\
(3336) \\
0.0000\end{array}$} & \multirow{2}{*}{$\begin{array}{c}\text { PCFTA_Differentiated } \\
\text { products } \\
0.8034^{* *} \\
(0.4101)\end{array}$} & \multirow{2}{*}{$\begin{array}{c}\text { (No. of Obs.) } \\
\text { Prob > chi2 } \\
(20992) \\
0.0000\end{array}$} \\
\hline $\begin{array}{l}\text { Pakistan exports to } \\
\text { China/row }\end{array}$ & Value & & & & \\
\hline & $\begin{array}{l}\text { Intensive } \\
\text { margin }\end{array}$ & $\begin{array}{l}-0.5498^{*} \\
(0.3074)\end{array}$ & $\begin{array}{l}(3336) \\
0.0000\end{array}$ & $\begin{array}{l}0.9308^{* *} \\
(0.4671)\end{array}$ & $\begin{array}{c}(20992) \\
0.0000\end{array}$ \\
\hline & $\begin{array}{c}\text { Extensive } \\
\text { margin }\end{array}$ & $\begin{array}{l}-0.2681^{* * *} \\
(0.1558)\end{array}$ & $\begin{array}{l}(3366) \\
0.0000\end{array}$ & $\begin{array}{l}0.1999^{* * * *} \\
(0.0781)\end{array}$ & $\begin{array}{c}(21052) \\
0.0000\end{array}$ \\
\hline \multirow[t]{3}{*}{$\begin{array}{l}\text { China exports to } \\
\text { Pakistan/row }\end{array}$} & Value & $\begin{array}{l}-0.8400^{* * * *} \\
(0.2232)\end{array}$ & $\begin{array}{l}(5955) \\
0.0000\end{array}$ & $\begin{array}{l}0.3979^{* * * *} \\
(0.1363)\end{array}$ & $\begin{array}{c}(52140) \\
0.0000\end{array}$ \\
\hline & $\begin{array}{l}\text { Intensive } \\
\text { margin }\end{array}$ & $\begin{array}{l}-0.9737^{\text {**** }} \\
(0.2099)\end{array}$ & $\begin{array}{l}(5955) \\
0.0000\end{array}$ & $\begin{array}{l}0.2882^{* * * *} \\
(0.1207)\end{array}$ & $\begin{array}{c}(52140) \\
0.0000\end{array}$ \\
\hline & $\begin{array}{c}\text { Extensive } \\
\text { margin }\end{array}$ & $\begin{array}{l}-0.0361 \\
(0.1041) \\
\end{array}$ & $\begin{array}{l}(5955) \\
0.0000 \\
\end{array}$ & $\begin{array}{l}0.0484^{* * * *} \\
(0.0257)\end{array}$ & $\begin{array}{c}(52140) \\
0.0000 \\
\end{array}$ \\
\hline \multirow[t]{3}{*}{$\begin{array}{l}\text { World exports to } \\
\text { Pakistan/row }\end{array}$} & Value & $\begin{array}{l}-0.2179^{* *} \\
(0.1166)\end{array}$ & $\begin{array}{l}(7758) \\
0.0000\end{array}$ & $\begin{array}{l}0.1106 \\
(0.1464)\end{array}$ & $\begin{array}{c}(52646) \\
0.0000\end{array}$ \\
\hline & $\begin{array}{l}\text { Intensive } \\
\text { margin }\end{array}$ & $\begin{array}{l}-0.0622 \\
(0.1593)\end{array}$ & $\begin{array}{l}(7728) \\
0.0000\end{array}$ & $\begin{array}{l}0.1405 \\
(0.1688)\end{array}$ & $\begin{array}{c}(52556) \\
0.0000\end{array}$ \\
\hline & $\begin{array}{c}\text { Extensive } \\
\text { margin }\end{array}$ & $\begin{array}{c}-0.0185 \\
(0.0444)\end{array}$ & $\begin{array}{l}(7787) \\
0.0000\end{array}$ & $\begin{array}{l}0.0216 \\
(0.0182)\end{array}$ & $\begin{array}{c}(52792) \\
0.0000\end{array}$ \\
\hline \multirow[t]{3}{*}{$\begin{array}{l}\text { World exports to } \\
\text { China/row }\end{array}$} & Value & $\begin{array}{l}-0.6044^{*} \\
(0.3373)\end{array}$ & $\begin{array}{l}(2436) \\
0.0000\end{array}$ & $\begin{array}{l}-1.2716^{*} \\
(0.7480)\end{array}$ & $\begin{array}{c}(16478) \\
0.0000\end{array}$ \\
\hline & $\begin{array}{l}\text { Intensive } \\
\text { margin }\end{array}$ & $\begin{array}{l}-0.4734^{*} \\
(0.2774)\end{array}$ & $\begin{array}{l}(2436) \\
0.0000\end{array}$ & $\begin{array}{l}-1.3502^{*} \\
(0.7496)\end{array}$ & $\begin{array}{c}(16478) \\
0.0000\end{array}$ \\
\hline & $\begin{array}{c}\text { Extensive } \\
\text { margin }\end{array}$ & $\begin{array}{c}-0.0015 \\
(0.0628)\end{array}$ & $\begin{array}{l}(2436) \\
0.0362\end{array}$ & $\begin{array}{c}-0.0438 \\
(0.0308)\end{array}$ & $\begin{array}{c}(16478) \\
0.0000\end{array}$ \\
\hline
\end{tabular}

${ }^{*} p<0.1,{ }^{* *} p<0.05,{ }^{* * *} p<0.01$.

FTA, free trade agreement.

extensive margin for China's exports to Pakistan/Row is found to be negative in the robustness test and positive in baseline estimation. However, this coefficient is found to be statistically insignificant in the robustness test. Moreover, in the World's exports to Pakistan/Row, the effect of Pakistan China FTA on the extensive margin is negative under the robustness test and positive under baseline estimation. However, it is essential to highlight that the baseline result still holds a higher validity under these differences. Moreover, the estimated results for second robustness test are shown in Table 4. According to these results, all the estimated coefficients in the second robustness tests are similar to the estimated coefficient of baseline estimation. Similarly, the coefficients obtained through third robustness test are also not different from the coefficient predicted in baseline results. However, the significance of the results in third robustness test are not very much higher as compare to the first and second robustness test. The results of third robustness test are presented in Table 5.

\section{Discussion and implications}

The result determined that the effect of the Pakistan-China FTA on China's export value, the export value of Pakistan, and the export value of the World to Pakistan are higher in the differentiated compared to the homogenous products. Therefore, the effect of trade liberalization under Bertrand competition between asymmetric countries is higher in differentiated products compared to homogenous commodities. Besides, the Pakistan-China FTA's impact on the value of world export to China is negative for both the differentiated product and homogenous products. In this context, the study suggests that if the effect is found to be negative for both the product categories, then the effect negative effect should be higher in the differentiated product as compared to the homogenous products.

Moreover, the effect of the Pakistan-China FTA on the extensive and intensive margins is found to be positive for the differentiated products in the case of Pakistan's exports to China. However, the effect of the Pakistan-China FTA is found to be negative on both intensive and extensive margins for the homogenous products. According to Chaney (2008), "a higher elasticity makes the intensive margin more sensitive to changes in trade barriers, whereas it makes the extensive margin less 
Table 4. Second Robustness test estimation for the Pakistan-China FTA

\begin{tabular}{|c|c|c|c|c|c|}
\hline \multicolumn{2}{|c|}{ Variable } & \multirow{2}{*}{$\begin{array}{c}\text { PCFTA_Homogenous } \\
\text { products } \\
1.0972^{* * * *} \\
(0.3496)\end{array}$} & \multirow{2}{*}{$\begin{array}{c}\text { (No. of Obs.) } \\
\text { Prob > chi2 } \\
(22050) \\
0.0000\end{array}$} & \multirow{2}{*}{$\begin{array}{c}\text { PCFTA_Differentiated } \\
\text { products } \\
-0.9842^{* * * *} \\
(0.3498)\end{array}$} & \multirow{2}{*}{$\begin{array}{c}\text { (No. of Obs.) } \\
\text { Prob > chi2 } \\
(2727) \\
0.0000\end{array}$} \\
\hline $\begin{array}{l}\text { Pakistan exports to } \\
\text { China/row }\end{array}$ & Value & & & & \\
\hline & $\begin{array}{l}\text { Intensive } \\
\text { margin }\end{array}$ & $\begin{array}{l}0.9795^{* * *} \\
(0.4458)\end{array}$ & $\begin{array}{c}(22050) \\
0.0000\end{array}$ & $\begin{array}{l}-0.8150^{* * * *} \\
(0.3298)\end{array}$ & $\begin{array}{l}(2727) \\
0.0000\end{array}$ \\
\hline & $\begin{array}{c}\text { Extensive } \\
\text { margin }\end{array}$ & $\begin{array}{l}0.2127^{* * *} \\
(0.0758)\end{array}$ & $\begin{array}{c}(22140) \\
0.0000\end{array}$ & $\begin{array}{l}-0.2819^{*} \\
(0.1621)\end{array}$ & $\begin{array}{l}(2742) \\
0.0000 \\
\end{array}$ \\
\hline \multirow[t]{3}{*}{$\begin{array}{l}\text { China exports to } \\
\text { Pakistan/row }\end{array}$} & Value & $\begin{array}{l}0.3011^{* *} \\
(0.1422)\end{array}$ & $\begin{array}{c}(55170) \\
0.0000\end{array}$ & $\begin{array}{l}-0.4635^{*} \\
(0.2637)\end{array}$ & $\begin{array}{l}(4380) \\
0.0000\end{array}$ \\
\hline & $\begin{array}{c}\text { Intensive } \\
\text { margin }\end{array}$ & $\begin{array}{l}0.3581^{* * * *} \\
(0.1039)\end{array}$ & $\begin{array}{c}(55170) \\
0.0000\end{array}$ & $\begin{array}{l}-0.9375^{* * * *} \\
(0.3320)\end{array}$ & $\begin{array}{l}(4380) \\
0.0000\end{array}$ \\
\hline & $\begin{array}{c}\text { Extensive } \\
\text { margin }\end{array}$ & $\begin{array}{l}0.0382^{*} \\
(0.0230)\end{array}$ & $\begin{array}{c}(55170) \\
0.0000\end{array}$ & $\begin{array}{l}0.0696 \\
(0.1261)\end{array}$ & $\begin{array}{l}(4380) \\
0.0000\end{array}$ \\
\hline \multirow[t]{3}{*}{$\begin{array}{l}\text { World exports to } \\
\text { Pakistan/row }\end{array}$} & Value & $\begin{array}{l}0.15844 \\
(0.1464)\end{array}$ & $\begin{array}{c}(55749) \\
0.0000\end{array}$ & $\begin{array}{l}-0.2261^{*} \\
(0.1264)\end{array}$ & $\begin{array}{l}(5598) \\
0.0000\end{array}$ \\
\hline & $\begin{array}{l}\text { Intensive } \\
\text { margin }\end{array}$ & $\begin{array}{l}0.2990^{* *} \\
(0.1714)\end{array}$ & $\begin{array}{c}(55749) \\
0.0000\end{array}$ & $\begin{array}{l}-0.2845^{* * *} \\
(0.1044)\end{array}$ & $\begin{array}{l}(5568) \\
0.0000\end{array}$ \\
\hline & $\begin{array}{c}\text { Extensive } \\
\text { margin }\end{array}$ & $\begin{array}{l}0.0303^{* *} \\
(0.0178)\end{array}$ & $\begin{array}{c}(55912) \\
0.0000\end{array}$ & $\begin{array}{l}0.0822^{*} \\
(0.0453)\end{array}$ & $\begin{array}{l}(5613) \\
0.0000\end{array}$ \\
\hline \multirow[t]{3}{*}{$\begin{array}{l}\text { World Exports to } \\
\text { China/Row }\end{array}$} & Value & $\begin{array}{l}-1.4534^{* *} \\
(0.6564)\end{array}$ & $\begin{array}{c}(17570) \\
0.0000\end{array}$ & $\begin{array}{l}-0.8538^{* * *} \\
(0.3457)\end{array}$ & $\begin{array}{l}(1820) \\
0.0000\end{array}$ \\
\hline & $\begin{array}{l}\text { Intensive } \\
\text { margin }\end{array}$ & $\begin{array}{l}-1.5247^{* *} \\
(0.6585)\end{array}$ & $\begin{array}{c}(17570) \\
0.0000\end{array}$ & $\begin{array}{l}-0.7140^{* * *} \\
(0.2796)\end{array}$ & $\begin{array}{l}(1820) \\
0.0000\end{array}$ \\
\hline & $\begin{array}{c}\text { Extensive } \\
\text { margin }\end{array}$ & $\begin{array}{l}-0.0544^{*} \\
(0.0300)\end{array}$ & $\begin{array}{c}(17570) \\
0.0000\end{array}$ & $\begin{array}{l}-0.0215 \\
(0.0728)\end{array}$ & $\begin{array}{l}(1820) \\
0.0000\end{array}$ \\
\hline
\end{tabular}

${ }^{*} p<0.1,{ }^{* *} p<0.05,{ }^{* * * *} p<0.01$.

FTA, free trade agreement.

sensitive. Chaney illustrates these phenomena as follows "When trade barriers decrease, new and less productive firms enter the export market. When the elasticity of substitution is high, low productivity is a severe disadvantage. These less productive firms can capture only a small market share. The impact of those new entrants on aggregate trade is small". Moreover, Sun et al. (2011) argues that the reduction in variable cost raises the intensive margin of the trade if the lower productivity firms have not only higher variable cost but also the higher fixed cost too. Thereby, these result of Pakistan's exports to China concludes opposite to the empirical implication of Sun and Chaney's theoretical assumptions.

Furthermore, the effect of Pakistan-China FTA on China's exports to Pakistan is found to be negative on the intensive margin and positive on the extensive margins for the homogenous products, whereas the effect of Pakistan-China FTA is found to be positive on both the extensive and intensive margins China's exports of differentiated products to Pakistan. According to Handley and Limão (2015) and Sala et al. (2010), the reduction in tariff mostly reduces or eliminates the uncertainty in the market and facilitates the entry of firms into the export market more significantly. Therefore, these result of China's exports to Pakistan concludes the empirical implication of Handley and Sala's theoretical assumptions. Correspondingly, the result of the World's exports to Pakistan also concluded that the effect of Pakistan-China FTA is found to be negative on the intensive margin and positive on the extensive margins for the homogenous products. Whereas the effect of the Pakistan-China FTA is found to be positive on both the extensive and intensive margins for the differentiated products. Consequently, the result of the World's exports to Pakistan also concludes the empirical implication of Handley and Sala's theoretical assumptions. Also, In the case of the World's exports to China, the effect of the Pakistan-China FTA on the extensive and intensive margins is found to be negative for both the differentiated and homogenous products. The effect of FTA on welfare is found to be consistent with the theoretical assumptions of this study. However, the result of extensive and intensive margin is found to be inconclusive and consider as the limitation of the study.

In addition, one of the most important policy implications provided by this study is that Pakistan's enterprises need to concentrate on differentiated products as compare to homogenous products. The results of this study concluded that PakistanChina FTA was more beneficial for China as compared to Pakistan. However, if Pakistani enterprises focus more on 
Table 5. Third Robustness test estimation for the Pakistan-China FTA

\begin{tabular}{|c|c|c|c|c|c|}
\hline \multicolumn{2}{|c|}{ Variable } & \multirow{2}{*}{$\begin{array}{c}\text { PCFTA_Homogenous } \\
\text { Products } \\
0.7975^{* *} \\
(0.4072)\end{array}$} & \multirow{2}{*}{$\begin{array}{c}\text { (No. of Obs.) } \\
\text { Prob > chi } 2 \\
(20992) \\
0.0000\end{array}$} & \multirow{2}{*}{$\begin{array}{c}\text { PCFTA_Differentiated } \\
\text { Products } \\
-0.6654^{*} \\
(0.3698)\end{array}$} & \multirow{2}{*}{$\begin{array}{c}\text { (No. of Obs.) } \\
\text { Prob > chi2 } \\
(3336) \\
0.0000\end{array}$} \\
\hline $\begin{array}{l}\text { Pakistan exports to } \\
\text { China/row }\end{array}$ & Value & & & & \\
\hline & $\begin{array}{l}\text { Intensive } \\
\text { margin }\end{array}$ & $\begin{array}{l}0.9249^{* *} \\
(0.4639)\end{array}$ & $\begin{array}{c}(20992) \\
0.0000\end{array}$ & $\begin{array}{l}-0.5498^{*} \\
(0.3074)\end{array}$ & $\begin{array}{l}(3336) \\
0.0000\end{array}$ \\
\hline & $\begin{array}{c}\text { Extensive } \\
\text { margin }\end{array}$ & $\begin{array}{l}0.1941^{* * *} \\
(0.0778)\end{array}$ & $\begin{array}{c}(21052) \\
0.0000\end{array}$ & $\begin{array}{l}-0.2662^{*} \\
(0.1554)\end{array}$ & $\begin{array}{l}(3336) \\
0.0000\end{array}$ \\
\hline \multirow[t]{3}{*}{$\begin{array}{l}\text { China exports to } \\
\text { Pakistan/row }\end{array}$} & Value & $\begin{array}{l}0.3892^{* * *} \\
(0.1342)\end{array}$ & $\begin{array}{c}(52140) \\
0.0000\end{array}$ & $\begin{array}{l}-0.8478^{* * *} \\
(0.2206)\end{array}$ & $\begin{array}{l}(5955) \\
0.0000\end{array}$ \\
\hline & $\begin{array}{l}\text { Intensive } \\
\text { margin }\end{array}$ & $\begin{array}{l}0.2785^{\text {*** }} \\
(0.1176)\end{array}$ & $\begin{array}{c}(52140) \\
0.0000\end{array}$ & $\begin{array}{l}-1.0161^{* * *} \\
(0.1999)\end{array}$ & $\begin{array}{l}(5955) \\
0.0000\end{array}$ \\
\hline & $\begin{array}{c}\text { Extensive } \\
\text { margin }\end{array}$ & $\begin{array}{l}0.0509^{* *} \\
(0.0256)\end{array}$ & $\begin{array}{c}(52140) \\
0.0000\end{array}$ & $\begin{array}{l}-0.0361 \\
(0.1042)\end{array}$ & $\begin{array}{l}(5955) \\
0.0000\end{array}$ \\
\hline \multirow[t]{3}{*}{$\begin{array}{l}\text { World exports to } \\
\text { Pakistan/row }\end{array}$} & Value & $\begin{array}{l}0.1159 \\
(0.1458)\end{array}$ & $\begin{array}{c}(52646) \\
0.0000\end{array}$ & $\begin{array}{l}-0.2181^{*} \\
(0.1183)\end{array}$ & $\begin{array}{l}(7758) \\
0.0000\end{array}$ \\
\hline & $\begin{array}{l}\text { Intensive } \\
\text { margin }\end{array}$ & $\begin{array}{l}0.1433 \\
(0.1687)\end{array}$ & $\begin{array}{c}(52556) \\
0.0000\end{array}$ & $\begin{array}{l}-0.0596 \\
(0.1616)\end{array}$ & $\begin{array}{l}(7728) \\
0.0000\end{array}$ \\
\hline & $\begin{array}{c}\text { Extensive } \\
\text { margin }\end{array}$ & $\begin{array}{l}0.0195 \\
(0.0183)\end{array}$ & $\begin{array}{c}(52792) \\
0.0000\end{array}$ & $\begin{array}{c}-0.0180 \\
(0.0448)\end{array}$ & $\begin{array}{l}(7787) \\
0.0000\end{array}$ \\
\hline \multirow[t]{3}{*}{$\begin{array}{l}\text { World exports to } \\
\text { China/row }\end{array}$} & Value & $\begin{array}{l}-1.2713^{*} \\
(0.7482)\end{array}$ & $\begin{array}{c}(16478) \\
0.0000\end{array}$ & $\begin{array}{l}-0.6037^{*} \\
(0.3372)\end{array}$ & $\begin{array}{l}(2436) \\
0.0000\end{array}$ \\
\hline & $\begin{array}{l}\text { Intensive } \\
\text { margin }\end{array}$ & $\begin{array}{l}-1.3499^{*} \\
(0.7497)\end{array}$ & $\begin{array}{c}(16478) \\
0.0000\end{array}$ & $\begin{array}{l}-0.4726^{*} \\
(0.2774)\end{array}$ & $\begin{array}{l}(2436) \\
0.0000\end{array}$ \\
\hline & $\begin{array}{c}\text { Extensive } \\
\text { margin }\end{array}$ & $\begin{array}{c}-0.0463 \\
(0.0308)\end{array}$ & $\begin{array}{c}(16478) \\
0.0000\end{array}$ & $\begin{array}{c}-0.0022 \\
(0.0626)\end{array}$ & $\begin{array}{l}(2436) \\
0.0000\end{array}$ \\
\hline
\end{tabular}

${ }^{*} p<0.1,{ }^{* *} p<0.05,{ }^{* * *} p<0.01$.

FTA, free trade agreement.

differentiated products as compared to homogenous products, then it will be equally beneficial for both Chinese and Pakistani enterprises. Moreover, these enterprises more on the average value of their exports with respect to the Chinese market. The benefit of the Pakistan-China FTA is mainly transferred through the new product with lower export value. Therefore, Pakistan`s enterprises should focus on the commodities which are higher in term of their value and hold higher demand in the big Chinese market. China's exports to Pakistan have been massively increased after the complete implementation of the Pakistan-China FTA. Although, Pakistan is not a very huge market for the Chinese exporter there are more opportunities for the Chinese exporter rather than just exporting their products to the Pakistani market. Pakistan-China FTA creates a strong commutation network between the business communities of both countries. China can effectively utilize this comminution by establishing their production line in Pakistan. The Chinese economy is moving toward a new phase of innovation which increases the cost of production in China. Therefore, Pakistan could be a better substitute for their product line at a lower production cost.

\section{Conclusion}

The study is attempted with two marginal contributes. Firstly, it contributes to the literature by considering the Bertrand competition between asymmetric countries and empirically finding out the FTA's effects on these three countries. Secondly, it addresses the ambiguity about the effect of the Pakistan-China FTA. The study explores the Pakistan-China FTA in the context of homogenous versus differentiated products to find better solutions for the improvement in the Pakistan-China FTA. Therefore, the study will be analyzing the export value and dual margin of trade for homogenous and differentiated commodities under the Pakistan-China FTA. The study employed the methodology of Pseudo Poisson Maximum Likelihood (PPML) for efficient estimation. The study concludes that the effect of FTA on the FTA and Non-FTA countries is greater on the differentiated product as compared to the homogenous product for asymmetric countries. Hence, this study suggested that Pakistan-China FTA is equally beneficial for both Chinese and Pakistani enterprises if Pakistani enterprises focus more on differentiated products as compared to homogenous products. Moreover, the bilateral trade between Pakistan and China can be 
more efficient if both countries utilized China-Pakistan Economic Corridor, a flagship project of the OBOR initiative more effectively.

\section{Study limitations}

There are some limitations in this study that could be addressed in future research. First, the study can be conducted in the context of more FTAs around the world to compare the results. Also, this analysis can be conducted for the firm-level data, depend on the data availability. Lastly, the study was not able to explain the results of the world's exports to China for extensive and intensive margin. Future work can be done to explain this result more significantly.

\section{References}

Ahmad, R. M., 2017. Pakistan-China bilateral trade: The future trajectory. Strategic Studies 37, 66-89.

Ashournia, D., Hansen, P. S., Hansen, J. W., 2013. Trade liberalization and the degree of competition in international duopoly. Review of International Economics 21, 1048-1059.

Aziz, Q., 1964. Relations between Pakistan and the People's Republic of China. In Sherwani, L. A. et al. Foreign Policy of Pakistan - Analysis. Allies Book, Karachi, Pakistan.

Bernhofen, M.D., 2001. Product differentiation, competition, and international trade. Canadian Journal of Economics/Revue Canadienne d'Economique 34, 1010-1023.

Brander, J. A., 1981. Intra-industry trade in identical commodities. Journal of International Economics 11, 1-14.

Brander, J., Krugman, P., 1983. A 'reciprocal dumping' model of international trade. Journal of International Economics 15, 313-321.

Chaney, T., 2008. Distorted gravity: The intensive and extensive margins of international trade. American Economic Review 98, 1707-1721.

Chang, Y. M., Xiao, R. F., 2015. Preferential trade agreements between asymmetric countries: Free trade areas (with rules of origin) vs. customs unions. Japan and the World Economy 33, 28-43.

Chaudhry, T., Jamil, N., Chaudhry, A., 2017. Pakistan's experience with the Pakistan-China FTA: Lessons For CPEC. The Lahore Journal of Economics 22, 1-24.

Collie, D. R., 1996. Gains and losses from unilateral free trade under oligopoly. Recherches Économiques de Louvain 62, 191202.

Collie, D. R., Mai Le, V. P., 2014. Product differentiation, the volume of trade, and profits under Cournot and bertrand duopoly. International Journal of the Economics of Business 22, 73-86.

Cordella, T., 1993. Trade liberalization and oligopolistic industries: A welfare appraisal. Recherches Économies de Louvain 59, 355-363.

Friberg, R., Ganslandt, M., 2005. Reciprocal dumping with bertrand competition, stockholm school of economics. Working Paper Series in Economics and Finance No. 592.

Fujiwara, K., 2009. Trade liberalization in a differentiated duopoly reconsidered. Research in Economics 63, 165-171.

Gürtzgen, N., 2002. Trade liberalization and union wages in a differentiated bertrand duopoly. Open Economies Review 13, 133-151.

Handley, K., Limão, N., 2015. Trade and investment under policy uncertainty: Theory and firm evidence. American Economic Journal: Economic Policy 7, 189-222.

Heckman, J. J., 1979. Sample selection bias as a specification error. Econometrica 47, 153-161.

Helpman, E., Melitz, M., Rubinstein Y., 2008. Estimating trade flows: Trading partners and trading volumes. Quarterly Journal of Economics 123, 441-487.

Javaid, U., Jahangir, A., 2005. Pakistan-China strategic relationship: A glorious journey of 55 years. Journal of the Research Society of Pakistan 52, 157-183.

Kabraji, R., 2012. The China-Pakistan Alliance: Rhetoric and limitations. Asia Programme Paper ASP PP 2012/01.

Kamal, J., Malik. M. H., 2017. Dynamics of Pakistan's trade balance with China. State Bank of Pakistan Staff Notes 04/17.

Kataria, J. R., Naveed, A., 2014. Pakistan-China social and economic relations. South Asian Studies 29, 395-410.

Kawabata, Y., Takarada, Y., 2015. Welfare implications of free trade agreements under bertrand and cournot competition with product differentiation. International Economics 142, 4-14. 
Kayani, F., Ahmed, M., Shah T., Kayani, U. N., 2013. China-Pakistan economic relations: Lessons for Pakistan. Pakistan Journal of Commerce and Social Sciences 7, 454- 462.

Kiyotaki, F., Miyakawa, T., 2013. Barriers to global free trade through bilateral agreements. Review of International Economics $21,536-548$.

Krzysztof, K., 2016. Liberalisation of international trade - the case of asymmetric countries. Central European Journal of Economic Modelling and Econometrics 8, 143-160.

Muhammad, S. I., Qi, X., 2015. Pakistan-China free trade agreement (PCFTA) treaty model: Capability, prospects, and disputes. Academic Research International 6, 53-60.

Musleh-ud, D., Ghani, E., Qadir, U., 2009. Recent experience and future prospects of Pakistan's trade with China. Lahore Journal of Economics 14, 87-110.

Saggi, K., 2006. Preferential trade agreements and multilateral tariff cooperation. International Economic Review 47, $29-57$.

Sala, D., Schröder, P. J. H., Yalcin, E., 2010. Market access through bound tariffs. Scottish Journal of Political Economy 57 , 272-289.

Shabir, S., Kazmi, R., 2007. Economic effects of the recently signed Pak-China free trade agreement. The Lahore Journal of Economics 12, 174-202.

Silva, J. M. C. S., Tenreyro, S., 2006. The log of gravity, The Review of Economics and Statistics 88, 641-658.

Sun, C., Tian, G., Zhang, T., 2013. An application of the melitz model to Chinese firms. Review of Development Economics 17, 494-509.

Wooldridge, J. M., 2006. Introductory Econometrics: A Modern Approach. South-Western College, Chula Vista, CA.

Yamamoto, K., 2014. FTA negotiations with side payments: Asymmetric countries and asymmetric information. Proceedings of the European Trade Study Group (ETSG), Sixteenth Annual Conference, Munich, Germary.

Yang, I., Kyung, J. M., 2014. Intra-industry trade with substitutes and complements under bertrand duopoly. The Journal of International Trade \& Commerce 10, 23-41.

Zada, N., Khan, K., 2017. General equilibrium analysis of Pakistan's free trade agreements: A global CGE approach. Proceedings of the Pakistan Society of Development Economists (PSDE), 33rd Annual General Meeting and Conference, Islamabad, Pakistan. 